\title{
EFFECT OF ANTIREFLUX THERAPY ON THE VOICE OUTCOMES OF PHONOMICROSURGERY FOR VOCAL FOLD POLYPS
}

\author{
Ezzat A. Merwad; Adely A. Tantawy; Hazem S.M. Amer and Alhusin G.A. Mohamed \\ Otorhinolaryngology Head and Neck Surgery, Faculty of Medicine - Zagazig University \\ ABSTRACT
}

Objective: to study the effect of antireflux therapy in the form of PPI and sodium alginate, on the voice outcome after phonomicrosurgery of vocal fold polyps. Study Design: All patients with vocal folds polyps were seen in the outpatient clinic and phoniatric unit of otorhinolaryngology department, Zagazig University Hospitals in the period from July 2016 to January 2018. Patients were divided into 2 groups one group received antireflux therapy in the form of proton pump inhibitors (omeprazole $20 \mathrm{mg}$ twice daily plus liquid alginate (gaviscon advance) one table spoonful $10 \mathrm{ml} 1 \times 3$ after meal and at bed time. The duration of treatment was 8 weeks. The other group wasn't received antireflux therapy postoperative. Results: A total of 24 patients met inclusion criteria and divided into two groups. In the two groups of 12 patients each from our study there was a statistically significant improvement regarding laryngeal evaluation, grades of dysphonia, the acoustic and aerodynamic parameters i.e. jitter $(\mathrm{p}=0.001)$, shimmer $(\mathrm{p}=0.02)$ and maximum phonation time $(\mathrm{p}=0.001)$ and AFF $(\mathrm{p}=0.04)$ in the group in which proton pump inhibitor and gaviscon advance were taken postoperative (group A) while in group B there is no Statistically significant difference in Average fundamental frequency.AFF, Jitter, Shimmer ( $\mathrm{p}$ value above 0.05 ), but there was statistically significant difference in HNR ( $\mathrm{p}=0.05$ ) and Maximal phonation time(MPT) ( $\mathrm{p}$ value 0.008 ).

Conclusion: The intake of combination of proton pump inhibitor and gaviscon advance liquid is beneficial if taken after phonomicrosurgery for vocal fold polyp to overcome the acidic and non acidic components of the reflux with statistically significant results

Key Words: Voice-Dysphonia-Phonomicrosurgery-Laryngopharyngeal reflux

Correspondence to : Alhusin G.A. Mohamed $\quad$ E-mail: drhusin90@gmail.com

Tel.: 01066325889

\section{INTRODUCTION}

V ocal fold polyps are common in the general population. They affect the vibratory vocal fold function resulting in significant dysphonia which is often surgically correctable ${ }^{\{1\}}$. They are confined to the superficial lamina propria (SLP) of the vocal folds $\{2\}$.

Nowadays, phonomicrosurgery is the most common treatment of vocal fold polyps, and became a new standard of care to remove pathology in these cases without scar formation. The term phonomicrosurgery was introduced in 1994, the principle of which lies in maximal preservation of the layered vocal folds microstructure, that is the epithelium and superficial lamina propria (SLP) ${ }^{\{3\}}$. It is fact that laryngopharyngeal reflux (LPR) plays an important role in pathogenesis of benign vocal fold mucosal lesion including polyps by its acidic (HCL) and non acidic (pepsin and other enzymes) component ${ }^{\{4\}}$. Its pathogenesis entails that its non acidic component (mainly pepsin) bound to tissue, acting as initiator, then acid component (HCL) activates it, acting as promoter, causing tissue damage and predisposing to vocal fold mucosal lesions ${ }^{\{5\}}$.

Laryngopharyngeal reflux become more prominent especially after meals (post prandial reflux) this is because gastric distention after meals result in transient loss of lower eosophageal sphincter competency and so increase gastroeosophageal reflux ${ }^{\{6\}}$.

Liquid alginate is used in treatment of symptoms of reflux disease for many years, sometimes in combination with proton pump inhibitors (PPIs) or H2-receptor antagonists. It is effective by producing a mechanical antireflux barrier within the stomach. The formation of barrier decrease risk for further symptoms due to reflux of gastric contents into the esophagus so, combination of proton pump inhibitors (PPIs) (act by decreasing acid component but not non acidic component of GERD) and liquid alginate (decrease acidic and non acidic component) is expected to give synergistic antireflux effect ${ }^{\{7\}}$. The aim of the work is to study the effect of antireflux, in the form of PPI and sodium alginate, on the voice outcome after phonomicrosurgery of vocal fold polyps. 


\section{METHODS}

\section{PATIENTS \& METHODS}

\section{Data accrual}

The present study was approved by the institutional review board at Faculty of Medicine, Zagazig University.

\section{Patient-based outcome measures}

Patients who fulfilled selection criteria were treated by cold phonomicrosurgery after videolaryngoscopy and voice assessment (grade of dysphonia scale and acoustic analysis) were done and patients were divided into two groups. One group received antireflux therapy in the form of proton pump inhibitors (omeprazole $20 \mathrm{mg}$ twice daily plus liquid alginate (gaviscon advance, Reckitt Benckiser Healthcare (UK)) one table spoonful $10 \mathrm{ml} 1 \times 3$ after meal and at bed time. The other group wasn't received antireflux therapy postoperatively. Re-evaluation of patients after two months using videolaryngoscopy and voice assessment using grade of dysphonia scale and acoustic analysis then compare preoperative and postoperative results between two groups.

\section{STATISTICAL ANALYSES}

Data were collected and entered using the statistic package SPSS V12.Data were summarized using mean, standard deviation (SD) and range for quantitative variables, and percent for qualitative variables.

Comparison between groups was done using $\mathrm{T}$ test, paired $\mathrm{T}$ test, and chi-square tests. P-values less than 0.05 were considered as statistically significant and p-values less than 0.001were considered as highly significant.

\section{RESULTS}

Twenty four patients were included in this study. Our patients were candidates of outpatient clinic and phoniatric unit of otorhinolaryngology dept. in Zagazig University Hospital. Patients were divided into two groups, group A which included 12 patients in which antireflux therapy in the form of proton pump inhibitor and gaviscon advance was taken postoperatively. and, group B which included 12 patients who didn't receive these medication postoperatively .
Table (1): shows that there is no statistically significant difference in patients' age, sex, special habits and jobs between group A and group B. Regarding age, Age ranged from 12 to 60 years in group A, and, from 21 to 60 years in group B. Regarding Gender, 9 patients $(75 \%)$ and 8 patients $(66.7 \%)$ are males in group A and B respectively, while 3 patients $(25 \%)$ of group A and 4 patients (33.3\%) of group B were females. Regarding special habits, $16.7 \%$ of group A was smokers compared to $33.3 \%$ of group B.

Table (2) shows that there is no statistically significant difference between both groups regarding disease onset, site of lesion, voice abuse and PND. There was four patients (33.3\%) of group A had GERD compared to ten patients $(83.4 \%)$ of group B.

Table (3) shows a statistically significant difference in AFF, HNR and Shimmer, while there was Statistically highly significant difference in jitter and MPT pre and post intervention in group A (with antireflux therapy) with high improvement postintervention. The highly statistically significance difference in MPT.

Table (4) shows that there is statistically highly significant difference in dysphonia pre and post intervention with absence of dysphonia in 8 patients $(66.7 \%)$ after surgery among group A (with antireflux therapy), while 4 patients $(33.3 \%)$ were resorted to grade I. As regard grade of dysphonia in group A (with antireflux therapy) in relation to the cases preoperatively and postoperatively, 8 patients $(66.7 \%)$ resorted to grade 0,4 patients $(33.3 \%)$ resorted to grade I with $\mathrm{p}$ value of 0.000 which means a Statistically significant difference. Table (5) shows a statistically significant difference in MPT and HNR pre and post intervention in control group, while regarding AFF, Jitter and Shimmer, there is no statistically significant difference in pre and post intervention among group B (without antireflux therapy). Table (6) shows that There was statistically significant difference in dysphonia grade pre and post intervention with 5 patients $(41.7 \%)$ resorted to grade I after surgery in group B (without antireflux therapy). Table (7) shows that group A with antireflux therapy has 
higher percent of improvement than group B without antireflux therapy

Table (1): Difference between group A and group B in socio-demographic characteristics

\begin{tabular}{|c|c|c|c|c|c|c|}
\hline Variables & \multicolumn{2}{|c|}{$\begin{array}{c}\text { Group A } \\
\text { (with antireflux) } \\
(\mathbf{n}=12)\end{array}$} & \multicolumn{2}{|c|}{$\begin{array}{c}\text { Group B } \\
\text { (without } \\
\text { antireflux) } \\
(n=12)\end{array}$} & t-test & P-value \\
\hline \multicolumn{7}{|l|}{ Age lyears } \\
\hline \multirow[t]{2}{*}{ Mean \pm SD } & \multicolumn{2}{|c|}{$\begin{array}{l}35.6 \pm 13.47 \\
12-60 \text { years }\end{array}$} & \multicolumn{2}{|c|}{$\begin{array}{c}39 \pm 11.62 \\
21-60 \text { years }\end{array}$} & 0.665 & 0.513 \\
\hline & $\mathbf{N}$ & $\%$ & $\mathbf{N}$ & $\%$ & & \\
\hline \multicolumn{7}{|l|}{ Sex } \\
\hline Male & 9 & 75 & 8 & 66.7 & 0.202 & 0.653 \\
\hline Female & 3 & 25 & 4 & 33.3 & & \\
\hline \multicolumn{7}{|l|}{ Job } \\
\hline Worker & 4 & 33.3 & $\mathbf{0}$ & 0.0 & & \\
\hline Employer & 6 & $\mathbf{5 0}$ & 5 & 41.6 & & \\
\hline Teacher & 1 & 8.3 & 4 & 33.3 & 8.86 & 0.07 \\
\hline Student & 1 & 8.3 & 1 & $\mathbf{0 . 0}$ & & \\
\hline HW(house wife) & $\mathbf{0}$ & 0.0 & 2 & 16.6 & & \\
\hline Smoker & 2 & 16.7 & 4 & 33.3 & 0.889 & 0.354 \\
\hline Not & 10 & 83.3 & 8 & 66.7 & & \\
\hline
\end{tabular}

Table (2); Difference between group A and group B in clinical history

\begin{tabular}{|c|c|c|c|c|c|c|}
\hline \multirow{3}{*}{$\begin{array}{l}\text { Disease onset } \backslash \text { month } \\
\text { Mean } \pm \text { SD }\end{array}$} & \multicolumn{2}{|c|}{$\begin{array}{c}\text { Group A } \\
\text { (with antireflux) } \\
(\mathrm{n}=12)\end{array}$} & \multicolumn{2}{|c|}{$\begin{array}{c}\text { Group B } \\
\text { (without } \\
\text { antireflux) } \\
(n=12) \\
\end{array}$} & \multirow{3}{*}{$\begin{array}{l}\text { t-test } \\
0.085\end{array}$} & \multirow{3}{*}{$\begin{array}{c}\text { P-value } \\
0.913\end{array}$} \\
\hline & \multicolumn{2}{|c|}{$\begin{array}{c}12.16 \pm 5.22 \\
5-24 \text { months }\end{array}$} & \multicolumn{2}{|c|}{$\begin{array}{c}12 \pm 4.22 \\
5-18 \text { months } \\
\end{array}$} & & \\
\hline & $\mathbf{N}$ & $\%$ & $\mathbf{N}$ & $\%$ & & \\
\hline $\begin{array}{l}\text { Site of VF polyp } \\
\text { Right } \\
\text { Left }\end{array}$ & $\begin{array}{l}8 \\
4\end{array}$ & $\begin{array}{l}66.7 \\
33.3\end{array}$ & $\begin{array}{l}7 \\
5\end{array}$ & $\begin{array}{l}58.3 \\
41.7\end{array}$ & 0.178 & 0.673 \\
\hline $\begin{array}{l}\text { GERD } \\
+ \text { ve } \\
\text {-ve } \\
\end{array}$ & $\begin{array}{l}4 \\
8 \\
\end{array}$ & $\begin{array}{l}33.3 \\
66.7 \\
\end{array}$ & $\begin{array}{c}10 \\
2 \\
\end{array}$ & $\begin{array}{l}83.4 \\
16.6 \\
\end{array}$ & 6.17 & 0.04 \\
\hline $\begin{array}{l}\text { Voice abuse } \\
\text { Yes } \\
\text { No }\end{array}$ & $\begin{array}{l}9 \\
3\end{array}$ & $\begin{array}{l}75 \\
25\end{array}$ & $\begin{array}{c}12 \\
0\end{array}$ & $\begin{array}{l}100 \\
0.0\end{array}$ & 3.43 & 0.06 \\
\hline $\begin{array}{l}\text { PND } \\
\text { Yes } \\
\text { No }\end{array}$ & $\begin{array}{l}9 \\
3\end{array}$ & $\begin{array}{l}75 \\
25\end{array}$ & $\begin{array}{l}8 \\
4\end{array}$ & $\begin{array}{l}66.7 \\
33.3\end{array}$ & 0.202 & 0.653 \\
\hline
\end{tabular}


Table (3); Difference in acoustic parameters before and after surgery among group A (with antireflux therapy)

\begin{tabular}{|c|c|c|c|c|}
\hline & $\begin{array}{c}\text { Pre-intervention } \\
\text { Mean SD } \\
\text { Median } \\
\text { Range }\end{array}$ & $\begin{array}{c}\text { Post-intervention } \\
\text { Mean SD } \\
\text { Median } \\
\text { Range }\end{array}$ & $\begin{array}{c}\text { t-test } \backslash \\
\text { wilcoxon }\end{array}$ & P-value \\
\hline $\begin{array}{l}\text { AFF } \\
\text { Normal=M: } \\
(100: 190) H z \\
\text { F:(180:260)Hz }\end{array}$ & $\begin{array}{c}215.5 \pm 103.9 \\
196.4 \\
110-495\end{array}$ & $\begin{array}{c}168.1 \pm 57.9 \\
1.54 \\
108.1-280.8\end{array}$ & $2.34^{*}$ & $0.04 *$ \\
\hline $\begin{array}{l}\text { Jitter } \\
\text { Normal }=(\text { up to } 1 \%)\end{array}$ & $\begin{array}{c}0.79 \pm 0.398 \\
.75 \\
0.25-1.66\end{array}$ & $\begin{array}{c}0.16 \pm 0.077 \\
.15 \\
0.01-0.3\end{array}$ & 5.75 & $0.001 * *$ \\
\hline $\begin{array}{l}\text { Shimmer } \\
\text { Normal= (up to 3\%) }\end{array}$ & $\begin{array}{c}2.72 \pm 1.54 \\
2.62 \\
0.74-5.99\end{array}$ & $\begin{array}{c}1.56 \pm 0.39 \\
1.6 \\
1.01-2.1\end{array}$ & $2.61^{*}$ & $0.02 *$ \\
\hline $\begin{array}{l}\text { HNR } \\
\text { Normal= }(15: 30)\end{array}$ & $\begin{array}{c}20.5 \pm 4.4 \\
22.2 \\
12.25-28.8\end{array}$ & $\begin{array}{c}26.8 \pm 4.11 \\
26.4 \\
21.2-35\end{array}$ & 3.46 & $0.005^{*}$ \\
\hline $\begin{array}{l}\text { MPT } \\
\text { Normal }=(20: 30 \mathrm{~s})\end{array}$ & $\begin{array}{c}11.7 \pm 3.7 \\
9 \\
5-25\end{array}$ & $\begin{array}{c}21.6 \pm 7 \\
23 \\
6.25-30\end{array}$ & $4.4^{*}$ & $0.001 * *$ \\
\hline
\end{tabular}

Table (4); comparing dysphonia before and after surgery among group $A$ (with antireflux therapy):

$\begin{array}{lllll}\begin{array}{l}\text { Pre-intervention } \\ (\mathrm{n}=12) .\end{array} & \begin{array}{l}\text { Post-intervention } \\ (\mathrm{n}=12)\end{array} & \mathbf{X}^{2} & \text { P-value }\end{array}$

\begin{tabular}{lllllll}
\hline Dysphonia & & & & & & \\
0 & 0 & 0.0 & 8 & 66.7 & 20.8 & $0.000 * *$ \\
I & 1 & 8.3 & 4 & 33.3 & & \\
II & 2 & 16.7 & 0 & 0.0 & & \\
III & 9 & 75 & 0 & 0.0 & & \\
\hline
\end{tabular}


Table (5); Difference in acoustic parameters before and after surgery among group B (without antireflux therapy)

\begin{tabular}{|c|c|c|c|c|}
\hline & $\begin{array}{c}\text { Pre-intervention } \\
\text { Mean SD } \\
\text { Median } \\
\text { Range }\end{array}$ & $\begin{array}{c}\text { Post-intervention } \\
\text { Mean SD } \\
\text { Median } \\
\text { Range }\end{array}$ & $\begin{array}{c}\text { t-testl } \\
\text { wilcoxon }^{\#}\end{array}$ & P-value \\
\hline AFF & $\begin{array}{c}202.5 \pm 77.6 \\
181.7\end{array}$ & $\begin{array}{c}177.2 \pm 50.6 \\
183.6\end{array}$ & $1.6^{\#}$ & 0.134 \\
\hline $\begin{array}{l}\text { Normal=M:(100:190)Hz } \\
F:(180: 260) H z\end{array}$ & $123-393$ & $120-267.1$ & & \\
\hline $\begin{array}{l}\text { Jitter } \\
\text { Normal= }(\text { up to } 1 \%)\end{array}$ & $\begin{array}{c}1.3 \pm 1.3 \\
.71 \\
0.22-4.5 \\
\end{array}$ & $\begin{array}{c}0.59 \pm 0.35 \\
.26 \\
0.16-0.93\end{array}$ & $1.39^{\#}$ & 0.07 \\
\hline $\begin{array}{l}\text { Shimmer } \\
\text { Normal= (up to } 3 \%)\end{array}$ & $\begin{array}{c}4.76 \pm 3.45 \\
3.38 \\
1.35-10.5 \\
\end{array}$ & $\begin{array}{c}4.02 \pm 2.59 \\
2.08 \\
1.01-3.17 \\
\end{array}$ & $0.984^{\#}$ & 0.151 \\
\hline $\begin{array}{l}\text { HNR } \\
\text { Normal= }(15: 30)\end{array}$ & $\begin{array}{c}23.35 \pm 2.34 \\
24.4 \\
3-25.8\end{array}$ & $\begin{array}{c}25.43 \pm 3.97 \\
24.7 \\
17.68-28.6\end{array}$ & 2.1 & $0.05^{*}$ \\
\hline $\begin{array}{l}\text { MPT } \\
\text { Normal=(20:30s })\end{array}$ & $\begin{array}{c}9.64 \pm 5.62 \\
8.3 \\
5-25\end{array}$ & $\begin{array}{c}19.56 \pm 7.82 \\
21 \\
6-30\end{array}$ & $2.67^{\#}$ & $0.008^{*}$ \\
\hline
\end{tabular}

Table (6); comparing dysphonia before and after surgery among group B (without antireflux therapy ):

\begin{tabular}{|c|c|c|c|c|c|c|}
\hline & \multicolumn{2}{|c|}{$\begin{array}{l}\text { Pre-intervention } \\
(n=12)\end{array}$} & \multicolumn{2}{|c|}{$\begin{array}{l}\text { Post-intervention } \\
(\mathrm{n}=12)\end{array}$} & \multirow{2}{*}{$\mathbf{X}^{2}$} & \multirow{2}{*}{ P-value } \\
\hline & $\mathbf{N}$ & $\%$ & $\mathbf{N}$ & $\%$ & & \\
\hline \multicolumn{7}{|c|}{ Dysphonia } \\
\hline I & 2 & 16.6 & 5 & 41.7 & & \\
\hline II & 5 & 33.3 & 7 & 58.3 & 6.62 & $0.03 *$ \\
\hline III & 5 & 50 & $\mathbf{0}$ & 0.0 & & \\
\hline
\end{tabular}

Table (7); comparing percentage of improvement after surgery in both groups.

\begin{tabular}{lcc}
\hline Variables & $\begin{array}{c}\text { Percent of } \\
\text { improvement } \\
\text { in group with antireflux }\end{array}$ & $\begin{array}{c}\text { Percent of improvement in } \\
\text { group without antireflux }\end{array}$ \\
\hline Mean decrease in AFF-F0 & $\mathbf{6 \%}$ & $\mathbf{3 \%}$ \\
\hline Mean decrease in jitter & $\mathbf{3 \%}$ & $\mathbf{1 \%}$ \\
\hline Mean decrease in shimmer & $\mathbf{5 \%}$ & $\mathbf{2 . 3}$ \\
\hline Mean improvement in HNR & $\mathbf{4 \%}$ & $\mathbf{1 . 5 \%}$ \\
\hline Mean improvement in MPT & $4.7 \%$ & $3 \%$ \\
\hline
\end{tabular}




\section{DISCUSSION}

Vocal fold polyps are benign lesions at the margin of one or both vocal folds which are considered to be hyperplastic formation of subepithelial tissue of the vocal folds ${ }^{\{8\}}$. Vocal fold polyps may be unilateral or bilateral. They also can be associated with other benign laryngeal lesions ${ }^{\{9\}}$, Vocal fold polyps vary greatly in shape, size and color. Some are circumscribed or even pedunculated. Others are broad-based and more diffuse affecting varying portions of the vocal folds ${ }^{\{10\}}$. Vocal fold polyps may respond to medical or behavioral treatments but usually require surgical removal which should be strictly confined to the lesion and care should be taken not to excise healthy tissue. A straight vocal fold edge, normal contour and minimum surgical wound should be the result ${ }^{\{11\}}$.

Laryngopharyngeal reflux (LPR) plays an important role in pathogenesis of benign vocal fold mucosal lesions including polyps

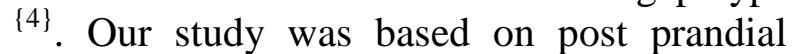
reflux which is a physiological process affecting both normal subjects and patients with gastroeosophageal reflux disease. It occurs due to two factors, the first is the increasing rate of lower eosophagial sphincter relaxations and competency due to gastric distention after meals ${ }^{\{6\}}$, the second factor is the formation of gasric acid pocket ${ }^{\{12\}}$. These two factors lead to increase gastroeosophageal reflux after meals.

In a study performed by Roh and Yoon, ${ }^{13\}}$; which was directed at studying the effect of acid and pepsin on glottis wound healing as a Simulated Reflux Model, this study found that glottis wound healing is significantly affected by acid and pepsin in the experimental study as simulated reflux model. They advocated antireflux treatment in patient who undergoes laryngeal surgery to minimize injury by gastroeosophageal reflux.

Based on the above, there was a concept of giving PPI after phonomicrosurgery, however PPI affects the acidic component of the reflux not the non acidic component.

Liquid alginate is a naturally occurring substance found in a particular type of seaweed which has been used in treatment of symptoms of reflux disease for many years, sometimes in combination with proton pump inhibitors (PPIs) or H2-receptor antagonists. It is effective by producing a mechanical antireflux barrier within the stomach and forms a 'raft' over the stomach contents, which helps prevent gastric reflux (both acidic and non acidic) coming back up into the oesophagus. The formation of barrier decrease risk for further symptoms due to reflux of gastric contents into the oesophagus. So, combination of proton pump inhibitors (PPIs) (act by decreasing acid component of GERD) and liquid alginate (decrease acidic and non-acidic component) is expected to give synergistic antireflux effect ${ }^{\{14\}}$.

Our study was designed to evaluate the effect of combined antireflux therapy in the form of proton pump inhibitor and sodium alginate in the form of gaviscon advance liquid (Reckitt Benckiser Healthcare (UK) (sodium alginate $(500 \mathrm{mg})+$ potassium bicarbonate $(100 \mathrm{mg})$ in every $5 \mathrm{ml})$ on the voice outcomes after phonomicrosurgery for vocal fold polyps.

In this study, Vocal fold polyps were found to be more frequent in males (17) than females (7). This observation may be explained by that in Egyptian males are more voice abusers, than females. The age of patients in the present study ranged between 12 and 60 years with a mean of $(35.6 \pm 13.47)$, Vocal fold polyps showed no statistically significant association with gender. Smoking causes the blood flow through vessels to decrease. It also increases carboxy hemoglobin ${ }^{\{15\}}$, with consequent reduction in the ability of hemoglobin to deliver oxygen to tissue leading to the possibility of thrombosis in the vocal fold mucosa. These deleterious effects of smoking lead to hypoxia and ischemia ${ }^{\{16\}}$. However in our study, 6 patients were smokers and so there is no significant role for smoking in our study.. In our study 14 patients had gastroesophageal reflux. 6 of them had a history of smoking.

The gastric fluid is highly acidic but the stomach lining cells have special properties to resist irritation from its acidic fluids. The lining cells of the throat and voice box are sensitive to the gastric fluid and exposure to 
stomach fluid reflux causes significant irritation to the voice box resulting in various abnormalities and voice disorders. In our study 16 patients had gastroesophageal reflux ${ }^{\{17\}}$. 4 of them had a history of smoking. Although reflux induced injury to the larynx was often referred to as posterior laryngitis, this term is inaccurate because it disregards the majority of laryngeal tissue injury that results from reflux ${ }^{\{18\}}$. In the present study, 21 patients had a history of voice abuse 14 of them had gastroesophageal reflux (history of treatment). All the factors were very intermingled and acting together to cause the development of the laryngeal mucosal lesions. So we can consider Vocal fold polyps as a multifactorial disease. All patients underwent videoendoscopic laryngeal evaluation, grading of dysphonia, acoustic and aerodynamic analysis in the preoperative and postoperative periods ( 2 months after surgery) and postoperative voice therapy for selected cases. The main line of treatment aims at improving voice function for patients to meet social and professional demands on voice.

For vocal fold polyp intraoperatively, general anaesthesia is induced using endotracheal intubation with a reasonably small diameter. Surgical microscope is used and it is practiced through direct "suspension laryngoscopy". Sharp instruments were used including special knifes, forceps and scissors. Endoscopic assessment of the field was done using a zero degree telescope, $4 \mathrm{~mm}$ diameter. The patients were divided into two groups, group A was received combined antireflux therapy in the form of proton pump inhibitors (omeprazole 20mg twice daily plus liquid alginate (gaviscon advance, Reckitt Benckiser Healthcare (UK)) one table spoonful $10 \mathrm{ml}$ $1 \times 3$ after meal and at bed time. The duration of treatment was 8 weeks. The other group B didn't receive antireflux therapy postoperatively.

Two months following surgery, videoendoscopic laryngeal evaluation, grading of dysphonia, acoustic and aerodynamic analysis were done. As regard grade of dysphonia in group A (with PPI and gaviscon advance intake) in relation to the cases preoperatively and postoperatively, 8 patients $(66.7 \%)$ resorted to grade 0,4 patients $(33.3 \%)$ resorted to grade I with $\mathrm{p}$ value of 0.000 which means a statistically highly significant difference $(\mathrm{P} \leq 0.001)$.

Regarding grades of dysphonia in group $\mathrm{B}$ (without antireflux therapy) in relation to the cases preoperatively and postoperatively, 5 patients $(41.7 \%)$ resorted to grade I, while 7 patients $(58.3 \%)$ resorted to grade II, with $\mathrm{p}$ value of 0.03 which means a statistically significant difference.

Comparing grades of dysphonia between group A and group B, there was Statistically highly significant difference in group $A$ and Statistically significant difference in group B, In group A 8 patients $(66.7 \%)$ resorted to grade 0 which mean no dysphonia unlike group B, all patients resorted to grade I and II not grade 0 .

As regard the acoustic parameters in group A (with antireflux therapy) in relation to the cases preoperatively and postoperatively, the Average fundamental frequency.(AFF) is reduced with ( $\mathrm{p}$ value of 0.04 ), the shimmer test ( $p$ value of 0.02 ), and Harmonic to noise ratio(NHR) ( $p$ value of 0.005 ), were reduced and there $\mathrm{P}$ value below 0.05 which means that there are statistically significant difference among cases preoperatively and postoperatively, the Jitter is reduced with ( $p$ value of 0.001), the Maximal phonation time(MPT) is increased with ( $\mathrm{p}$ value 0.001 ) which means that there were Statistically highly significant difference.

Regarding the acoustic parameters in group B (without antireflux intake) in relation to the cases preoperatively and postoperatively, there is no statistically significant difference in average fundamental frequency.AFF, Jitter and Shimmer ( $\mathrm{p}$ value above 0.05). but in the Harmonic to noise ratio(NHR) ( $\mathrm{p}$ value 0.05 ) and Maximal phonation time (MPT) ( $\mathrm{p}$ value 0.008) there are statistically significant difference among cases preoperatively and postoperatively(P value $\leq 0.05$ )

Comparing the acoustic parameters postoperatively between group A and group B; all acoustic parameters show Statistically significant difference $(\mathrm{P} \leq 0.05)$ except MPT and jitter show Statistically highly significant 
difference $(\mathrm{P} \leq 0.001)$ in group $\mathrm{A}$. while no Statistically significant difference in all acoustic parameters in group B except, $\operatorname{MPT}(\mathrm{P}=0.008)$ and HNR $(\mathrm{P}=0.05)$.

In a study performed by Lee et al ${ }^{\{19\}}$ (prospective randomized controlled study); A total of 48 cases of hoarseness of voice due to vocal fold polyps were studied. The study was directed at comparing the results of surgery on voice outcome with and without the use of antireflux therapy (in the form of proton pump inhibitor only which work only on acid component of reflux. this study concluded that Postoperative PPI treatment did not significantly influence voice outcomes after phonomicrosurgery in patients with vocal fold polyps.

In a study performed by Ruiz, et al ${ }^{\{20\}}$; a total of 51 cases of benign vocal fold lesion including polyps were studied. The study was directed at comparing the outcome of surgery with and without the use of antireflux therapy (ART) in the perioperative period in a preliminary retrospective study. The study parameters were Voice Handicap Index (VHI)-10 and Reflux Symptom Index (RSI) scores, Both $t$ test and regression analyses confirmed no statistical significant difference between the ART and non-ART and this study conclude that antireflux medications did not significantly influence outcomes after phonomicrosurgery in patients with benign vocal fold lesions including polyps.

In a study performed by Kantas et al ${ }^{\{21\}}$; a total of 112 cases of benign vocal fold lesion including polyps who suffered from LPR (diagnosed by history and $24 \mathrm{~h} \quad \mathrm{pH}$ monitoring). The study was to evaluate the effect of laryngopharyngeal reflux on the healing process of surgical laryngeal trauma in a prospective study. Within the group of patients who didn't take PPI, six patients presented granulation tissue or recurrence of the polyps and in two of them revision surgery was needed. RFS and RSI scores showed significant improvement postoperatively, across all the three groups of patients (third group with no LPR), with major differences observed in the group treated by PPI. Comparison of the postoperative RFS and RSI scores between the two groups of patients with LPR showed statistically significant differences in both, indicating better treatment outcome in those patients who had received PPI. It may be thus concluded that LPR influences epithelization and recurrence of laryngeal polyps or Reinke edema in vocal cords, after partial or total decortication. Surgical outcome is superior in patients with LPR with preoperative and postoperative anti-reflux treatment.

\section{CONCLUSION}

The intake of combined proton pump inhibitor and gaviscon advance liquid is beneficial if taken after phonomicrosurgery for vocal fold polyp to overcome the acidic and non acidic components of the reflux with statistically significant results, Therefore, we recommend the intake of proton pump inhibitors with sodium alginate in the form of gaviscon advance liquid after phononomicrosurgery of vocal fold polyp to enhance voice outcomes.

For our knowledge, this is the first prospective study about the effect of combined administration of PPIs and sodium alginate (in the form of gaviscon advance) postoperatively after phonomicrosurgery for patients with vocal fold polyps. We hope this study to be the core for further studies in the future on a larger numbers of patients and for a prolonged time of follow up.

\section{REFERENCES}

1. Schindler A, Mozzanica F, Ginocchio D, Maruzzi P, Atac M, Ottaviani F (2012): Vocal improvement after voice therapy in the treatment of benign vocal fold lesions. ACTA Otorhinolaryngologica Italica; 32: 304-308.

2. Thomas G, Mathews S, Chrysolyte SV. Rupa (2007): Outcome analysis of benign vocal cord lesions by videostroboscopy, acoustic analysis and voice handicap index . Indian J. Otolaryngol. and Head and Neck Surg; 59,336340.

3. Sataloff R, Spiegel R, Heuer J. Margaret M, Kate A, Mary J, Caputo D (1995) : Laryngeal mini-microflap :, A new technique and reassessment of the microflap saga. J voice; 9 : 198-204.

4. Koufman JA (2009): Perspective on Laryngopharyngeal Reflux: From Silence to Omnipresence. Classics in Voice and Laryngology. Branski R, Sulica L, Eds. Pages 179-266, Plural Publishing, San Diego. 
5. Koufman JA, Stern JC, Bauer MM (2010): Dropping Acid: The Reflux Diet Cookbook \& Cure. Reflux Cookbooks LLC (Midpoint Distributors), New York, NY.

6. Holloway RH, Kocyan p, and Dent j (1991): provocation of transient lower eosophageal sphincter relaxations by mealsin patients with symptomatic gastroeosophageal reflux.Dig,Dis,Sci.

7. McGlashan JA, Johnstone LM, Sykes J, Strugala V, Dettmar PW (2009): The value of a liquid alginate suspension (Gaviscon Advance) in the management of laryngopharyngeal reflux, Eur Arch Otorhinolaryngol. ;266(2):243-51.

8. Linda Rammage, Morrison, Hamish Nichol (2011): Management of the voice and its disorders, published by: Singular/Thomson Learning, San Diego, CA 269-270.

9. Hirano M, Cobeta I, Lara A, Fernando Garcia, Francisco Javier Gamboa (2008); Vocal pathologies of difficult diagnosis. J Voice. 22:607-610.

10. John MM (2007): Update on the etiology, diagnosis, and treatement of vocal fold nodules, polyps, and cysts. Curr Opin Otolaryngol Head Neck Surg; 11: 456-61.

11. Sataloff RT, Spiegel JR, Hawkshaw M, Jones A (2008): Laser surgery of the larynx: The case for caution. Ear Nose and Throat Journal, 92,593-595.

12. Kahrilas P.J, Kenneth McColl, Mark Fox, Lisa ORourke, Daniel Sifrim, Andre J.P.M.Smout, Guy Boeckxstaens (2013): the acid pocket:a target for treatment in reflux disease, the amrican Journal of Gastroenterology 108,1058-1064

13. Roh and Yoon (2006): Effect of acid and pepsin on glottic wound healing: a simulated reflux model Arch Otolaryngol Head Neck Surg. 2006 Sep;132(9):995-1000

14. McGlashan JA, Johnstone LM, Sykes J, Strugala V, Dettmar PW (2009): The value of a liquid alginate suspension (Gaviscon Advance) in the management of laryngopharyngeal reflux, Eur Arch Otorhinolaryngol ;266(2):243-51.

15. Brody S, and Coburn F (1969): Carbon monoxide-induced arterial hypoxemia. Science; 164: 1297-1298.

16. Sato K, Hirano M, Nakashima T (2003): 3D structure of the macula flava in the human vocal fold. Acta Otolaryngol. ;123(2):269-73

17. Koufman JA, Johnston N (2012): Potential Benefits of pH 8.8 Alkaline Drinking Water as an Adjunct in the Treatment of Reflux
Disease. Ann Otol Rhinol Laryngol 121:43134.

18. Belafsky C (2003): Abnormal endoscopic pharyngeal and laryngeal findings attributable to reflux. Am J Med; 115:90-96.

19. Lee YS, Lee DH, Jeong GE, Kim JW, Roh JL, Choi SH, Kim SY, Nam SY (2017): Treatment Efficacy of Voice Therapy for Vocal Fold Polyps and Factors Predictive of Its Efficacy J Voice ;31(1):120.e9-120.e13.

20. Ryan Ruiz, Achlatis S1, Sridharan S1, Wang B, Fang Y, Ryan C, Branski, Milan R (2014) : The effect of antireflux therapy on phonomicrosurgical outcomes J Voice ;28(2):241-4. doi: 10.1016/j.jvoice.2013.09.005. Epub 2013 Dec 8

21. Kantas, Dimitrios G, Belatsouras,Nikolaos Kamargians, Micheal Katotomichelakis, Maria Riga, Vasilis Danielidis (2009):the influence of laryngopharyngeal reflux in the healing of laryngeal trauma ,eyropean archieves of oto-rhino-laryngology 266 (2): 253-259. 